\title{
MENELAAH TERITORIALITAS KELOMPOK SOSIAL PENGHUNI DI RUSUNAWA: PROSES HOME-MAKING WARGA RELOKASI
}

\author{
Rossa Turpuk Gabe ${ }^{1, *}$, Annisa Putri Lestari ${ }^{2}$ \\ ${ }_{1}^{1}$ Arsitektur, Fakultas Teknik, Universitas Indonesia, Depok, 16424 \\ ${ }^{2}$ Arsitektur, Fakultas Teknik, Universitas Indonesia, Depok, 16424 \\ * rossa.simatupang@eng.ui.ac.id
}

\begin{abstract}
ABSTRAK. Makna rumah tidak hanya pada kehadiran bangunan fisiknya saja, tetapi juga kehadiran ruang yang membuat rasa aman, nyaman dan kepemilikan penghuninya. Tulisan ini mencoba untuk membahas proses Home-Making dengan mengangkat sebuah kasus relokasi warga kampung padat ke Rumah Susun Sederhana Sewa (Rusunawa). Perbedaan mendasar pada hunian sebelum dan sesudah relokasi adalah kemampuan ruang huni yang tersedia mewadahi interaksi sosial warga. Melalui kasus ini dapat terlihat pembentukan teritori di rusunawa yang dikontrol dan dikuasai kelompok-kelompok sosial bedasarkan kebutuhan setiap kelompok. Teritorialitas tersebut merupakan upaya kelompok sosial mengklaim suatu area geografis yang didasari dengan kebutuhan interaksi kelompoknya. Kebutuhan privasi dan elemen ruang memiliki peran penting dalam menciptakan teritori. Metode yang digunakan dalam penelitian ini adalah kualitatif dengan mengangkat Rusunawa Jatinegara Barat sebagai kasus. Rusunawa Jatinegara Barat dipilih karena rusun ini dikhususkan untuk warga relokasi Kampung Pulo yang telah rampung perpindahan seluruh warganya pada bulan Agustus 2015. Dalam rentang waktu huni tersebut, warga relokasi sudah menyesuaikan dengan lingkungan barunya. Bedasarkan hasil penelitian ini dapat disimpulkan bahwa pembentukan teritori kelompok sosial warga di rusunawa merupakan proses home-making penghuni relokasi kampung padat untuk menghadirkan kembali suasana dan nilai-nilai 'rumah' yang mereka yakini. Proses homemaking ini diharapkan mampu meningkatkan rasa kepemilikan penghuni seiring tanggung jawab dalam menjaga dan memelihara lingkungan tempat tinggalnya.
\end{abstract}

Kata kunci: teritorialitas, home-making, kelompok sosial, rumah susun

ABSTRACT. The Meaning of Home is not only about the existence of its physical building, but also the existence of a space where the owners feel safe, comfortable and belong to it. This paper addresses processes of Home-Making of a relocation case of crowded kampong's residents to Rental Low-cost Apartments (Rusunawa). The basic difference between before and after settlements is the ability of housing space to accommodate social interaction of residents. The case explains the formation of territory in Rusunawa that controlled and owned by specific social groups based on their needs. The territoriallity factor is an effort of social groups to claim a particular geographic area based on their interaction needs. The needs of privacy and space elements are important roles to create their territory. This study used a qualitative method with the case at Rusunawa Jatinegara Barat. Rusunawa Jatinegara Barat was chosen because it has been devoted to Kampung Pulo's people who was moved in August 2015. During the settlement period, the relocation residents have adapted to their new neighborhood. The findings of this study suggest that the formation of social groups resident in Rusunawa is a process of home-making of crowded kampong's residents to represent their concept of the atmosphere and values of home. These processes of home-making are expected able to increase resident's sense of belonging and increase their responsibility to maintain and preserve their neighborhood.

Keywords: territoriality, home-making, social groups, low-cost apartment

\section{PENDAHULUAN}

Rumah merupakan kebutuhan dasar manusia, sehingga pemenuhannya tidak hanya pada aspek teknis yang menjamin kekuatannya [1]. Rumah tidak hanya terkait dengan fisik bangunan atau lokasinya tetapi juga memiliki makna ruang dimana penghuni merasa aman, nyaman dan rasa memiliki [2]. Rumah juga merupakan wadah kehidupan sosial dan budaya [3]. Dalam hal ini, rumah memberikan peran sebagai tempat yang mewadahi manusia untuk berinteraksi dan beraktivitas dengan lingkungan sekitar: teman, tetangga, keluarga [4].

Masalah penyediaan perumahan sektor formal di kota dengan lahan terbatas dominan di dekati dengan pendekatan empirik berdasarkan logika sederhana, yakni, permintaan-pemasokan (supply-demand). Rumah pada posisi ini merupakan materialitas 
yang diperjual-belikan dan mengabaikan konteks sosio-kultural yakni kultur bermukim masyarakat kampung itu sendiri. Pendekatan ini dianggap sebagai akar dari masalah sosial saat masyarakat kampung padat direlokasi ke rumah susun. Relokasi warga kampung dianggap hanya 'memindahkan' manusianya tetapi luput pada kultur bermukim masyarakat di kampung tersebut.

Rumah susun merupakan salah satu ragam rumah yang dibangun oleh pemerintah untuk memenuhi kebutuhan hunian bagi warga relokasi. Namun, perancangan rumah susun seringkali sarat dengan masalah ketidakmampuannya mewadahi interaksi sosial warga yang merupakan bagian dari kultur bermukim masyarakat kampung. Selain itu, penghuni tidak dapat melakukan intervensi fisik ruang pada rumah susun sederhana sewa (Rusunawa) untuk menciptakan ruang komunal bagi kebutuhan interaksi sosial mereka.

Sebagai makhluk hidup yang sosial, berakal, dan berbudaya, manusia membutuhkan rasa penguasaan dan pengawasan, yang mana dapat membuat manusia merasa lebih bertanggung jawab terhadap lingkungannya [4]. Menumbuhkan rasa tanggung jawab tersebut memerlukan pastisipasi aktif dari setiap individu.

Dalam praktek merumah, individu/kelompok akan cenderung menciptakan teritori yang dapat mereka pelihara dan pertahankan saat mereka sudah merasa menjadi bagian dari suatu lingkungan tersebut. Tulisan ini mencoba untuk membahas fenomena ini dengan mengangkat sebuah kasus pembentukan teritori kelompok-kelompok sosial pada rusunawa. Meskipun terdapat keterbatasan pada lahan, fisik bangunan dan status sewa di Rusunawa, di dalamnya ternyata masih memiliki eksistensi ruang-ruang sosial-budayanya, yaitu ruang komunal atau ruang berkumpul yang diciptakan oleh kelompok-kelompok sosial rusun. Diskusi kasus ini merupakan upaya menggali terjadinya proses home-making warga relokasi kampung padat di rusunawa dengan pembentukan teritori yang diwujudkan dalam bentuk eksistensi ruang berkumpul/ ruang komunal.

\section{Teritorialitas sebagai Proses Home-Making}

Teritorialitas merupakan upaya individu/ kelompok untuk memberikan pengaruh dengan melakukan pengontrolan terhadap terhadap objek, manusia, dan relasi yang membatasi dan menegaskan kontrol pada teritori [5]. Teritorialitas akan dicapai dengan melakukan perilaku-perilaku teritorial. Perilaku teritorial adalah pengaturan batas fisik yang jelas dan/atau personalisasi karakter lingkungan. [6] Perilaku teritorial atau penandaan yang dilihat dari perspektif sosial dalam teritorialitas, memperlihatkan identitas yang ditampilkan dan regulasi sistem sosial dalam sebuah teritori. Manusia memiliki cara yang berbeda-beda dalam melakukan penandaan dan merespon gangguan berdasarkan tipe-tipe teritori dan bentuk fisiknya [7]

Suatu area yang dikontrol oleh individu/ kelompok yang dititik beratkan pada kepemilikan secara fisik disebut dengan teritori [6]. Dengan melakukan teritorialitas, maka individu/kelompok akan mendapatkan penguasaan atas pengontrolan terhadap segala sesuatu yang berada dalam teritorinya. Teritorialitas dilakukan sebagai ekspresi dari identitas (identity), personalisasi (personalization), rasa kepemilikan, dan keamanan (security). Hal ini yang menjelaskan mengapa manusia memerlukan teritorialitas dan membangun teritori dimanapun mereka tinggal dan hidup [6].

Teritori dapat diciptakan dengan fitur-fitur desain yang memiliki makna sebenarnya dan makna simbolis [6]. Batas-batas dengan makna sebenarnya merujuk pada elemen desain fisik seperti dinding dan pagar. Sedangkan, batas-batas dengan makna simbolis merujuk pada elemen desain seperti perubahan tekstur permukaan jalan dan tanaman-tanaman yang disusun dengan tujuan untuk membatasi suatu teritori. Menurut Pierce, teritori bersifat dinamis, multidimensional, dan dapat berubah dari waktu ke waktu. Teritori dan batas-batasnya dapat berubah-ubah, baik itu berpindah, menghilang, meluas, atau mengecil. Batas-batas yang hadir menentukan bagaimana sebuah objek atau lingkungan akan digunakan dan dikontrol oleh individu/kelompok yang menempati teritori tersebut.[8]

Teritorialitas yang dilakukan pada lingkungan tempat tinggal yang baru merupakan bagian dari proses dinamika penghuni untuk menghadirkan suasana dan nilai-nilai 'rumah' yang mereka yakini. Proses ini yang disebut dengan proses home-making. Proses ini merupakan respon afektif penghuni untuk menghadirkan rasa 'rumah' di suatu tempat barunya [9]. 
Dalam proses home-making, setiap individu memiliki kemampuan yang berbeda-beda untuk bernegosiasi pada kultur yang mereka temui di tempat yang baru [9]. Kesamaan kebutuhan dan tujuan pada kelompokkelompok penghuni akan membantu setiap individu untuk mencapai rasa aman, nyaman serta rasa kepemilikan di hunian barunya. Pada studi kasus Rusunawa Jatinegara Barat, kondisi sosial keseharian warga di kampung sebelumnya menjadi penggerak dialog dengan ruang-ruang hunian di Rusunawa.

Menanggapi fenomena di atas, maka studi kasus Rusunawa Jatinegara Barat dalam tulisan ini akan mencoba untuk menjawab pertanyaan: "Teritorialitas seperti apa yang dilakukan oleh penghuni Rusunawa Jatinegara Barat sebagai bagian dari proses homemaking penghuni di hunian barunya?" Secara khusus studi kasus ini akan menggali: "Penandaan teritori seperti apa yang dilakukan penghuni dan tujuan penandaan teritori tersebut sebagai bagian dari upaya meningkatkan kualitas hidup di hunian baru?".

\section{Tujuan dan Manfaat Penelitian}

Penelitian ini bertujuan untuk mengungkap teritorialitas kelompok-kelompok sosial yang ditemukan di Rusunawa sebagai upaya penelusuran proses merumah warga relokasi kampung padat di hunian yang baru. Pembentukan teritolitas tersebut dapat ditandai dari berbagai aspek, seperti identitas, personalitas, privasi, elemen arsitektural, dan interaksi sosialnya.

Hasil penelitian dapat memberikan manfaat berupa masukan bagi penyedia hunian bagi Masyarakat Berpenghasilan Rendah (MBR) khususnya bagi warga relokasi kampung padat yang selama ini kurang mempertimbangkan kultur bermukim penghuni, sehingga diharapkan hunian yang tersedia dapat meningkatkan kualitas hidup penghuninya.

\section{METODE PENELITIAN}

Metode yang digunakan dalam melakukan penelitian ini adalah kualitatif dengan pendekatan studi kasus. Pada dasarnya, penelitian ini dilakukan dengan melihat fenomena yang terjadi, pengamatan dan wawancara ke subjek-subjek yang menjadi fokus penelitian, yang kemudian dikembangkan pemahamannya secara mendalam. Dengan demikian, pendekatan studi kasus yang digunakan membuat pembahasan penelitian terfokus pada satu kasus yang kemudian dibahas secara mendalam, intensif, dan komprehensif. Penelitian ini juga memiliki batasan dalam fokus pembahasannya dan menentukan apa yang menjadi objek dari penelitian. Pembahasan pada penelitian ini dibatasi dengan studi kasus yang dilakukan pada Rusunawa Jatinegara Barat, karena Rusun ini dikhususkan untuk warga relokasi Kampung Pulo yang telah rampung perpindahan seluruh warganya pada bulan Agustus 2015. Proses penghunian yang sudah cukup lama dapat lebih memperlihatkan bahwa penghuni sudah mulai dapat menyesuaikan diri dengan lingkungannya.

Batasan pembahasannya menyangkut ruang berkumpul atau teritori yang dibentuk oleh kelompok-kelompok sosial dalam penelitian ini. Dilihat dari cara subjek-subjek tersebut membentuk teritori dan perilaku teritorial, yang mempengaruhi pengontrolan penghuni terhadap batas teritori dalam menciptakan ruang berkumpul atau ruang komunal berdasarkan kebutuhannya.

\section{HASIL DAN PEMBAHASAN}

\section{Gambaran Umum Rusunawa Jatinegara Barat}

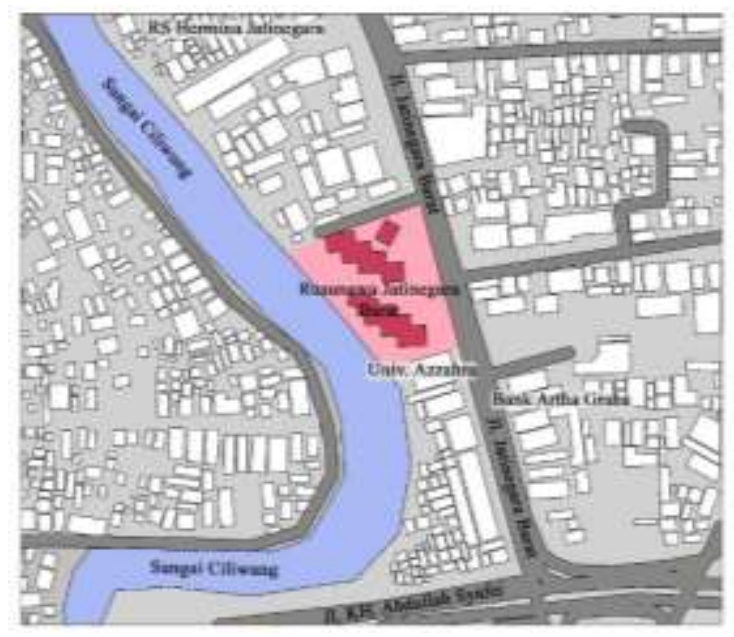

Gambar 1. Lokasi Rusunawa Jatinegara Barat (Sumber: Dokumentasi Pribadi, 2017)

Rusunawa Jatinegara Barat terletak pada Jalan Jatinegara Barat, Jakarta Timur. Rusun yang dibangun oleh Kementrian PU dengan dana APBN ini sepenuhnya dihuni oleh warga yang direlokasi dari Kampung Pulo dalam rangka normalisasi Sungai Ciliwung. Rusunawa Jatinegara Barat mulai dibangun tahun 2014 dan mulai dihuni pada pertengahan tahun 2015 . 
Rusunawa terdiri dari dua tower, 16 lantai dan 520 unit hunian dengan luasan $30 \mathrm{~m}^{2}$ setiap unitnya. Fasilitas yang dimiliki Rusunawa di antaranya 2 lift barang, 8 lift orang, area parkir motor, area parkir mobil, PAUD, perpustakaan, taman, lobi, aula, masjid, klinik, dan area untuk berjualan untuk penghuni.

Rusunawa Jatinegara Barat terdiri dari satu Rukun Warga (RW), yaitu RW 09. Unit hunian ditentukan secara acak, sehingga apabila dalam lingkungan Kampung Pulo ada yang rumahnya bertetangga, bisa saja di Rusunawa mereka tinggal di lantai yang berbeda. Namun, secara keseluruhan seluruh warga yang ada di Rusunawa sudah tidak asing lagi dan mengenal satu dengan yang lainnya.

\section{Klasifikasi Kelompok Sosial Penghuni Rusunawa}

Manusia memiliki naluri untuk selalu berhubungan dengan sesamanya. Menurut Soekanto [10], hubungan yang berkesinambungan antar manusia menghasilkan pola pergaulan yang dinamakan pola interaksi sosial. Pergaulan dan interaksi sosial yang manusia bangun dapat menciptakan perubahan atau penambahan pandangan-pandangan yang dimilki oleh individu yang bersangkutan.

Menurut Soekanto [10] kelompok sosial adalah kelompok yang berkumpul atas dasar kepentingan yang sama, artinya mereka memiliki kebutuhan, kegiatan, dan tujuan yang sama saat mereka sedang berkumpul. Adanya kesamaan-kesamaan ini menjadi pemicu untuk mencari lokasi atau posisi yang tentunya akan mereka jadikan teritorinya. Setiap kelompok sosial memiliki teritori yang berbeda-beda dari segi privasi dan kebutuhan elemen fisik ruang. Hal tersebut terjadi karena masing-masing dari kelompok sosial ini memiliki sudut pandang yang berbeda akan tingkat teritori dan privasi yang menjadi kebutuhannya.

Secara sederhana identifikasi suatu kelompok terlihat jelas dari adanya sekumpulan orangorang yang berdiri/duduk pada satu titik dengan intim. Berdasarkan pengamatan dan hasil wawancara dengan kelompok-kelompok sosial (tabel 1), terbentuknya suatu kelompok sosial di Rusunawa dipengaruhi oleh usia, derajat interaksi sosial, tujuan, jenis kegiatan, dan kedekatan area hunian.

\section{Penandaan Teritorialitas Kelompok Sosial}

Kelompok sosial penghuni Rusunawa menciptakan teritori dengan melakukan penandaaan (marking) baik dengan menggunakan tubuh maupun dengan berbagai objek-objek teritori yang hadir dari kegiatan atau ruang. Sebagian besar penanda teritorial pada ruang teritori yang terjadi menggunakan tubuh atau elemen ruang yang telah ada. Status sewa hunian mempengaruhi pada minimnya intervensi objek-objek permanen tambahan dalam ruang. Penandaan yang dihadirkan dapat menjadi tolak ukur dari level teritori yang bersangkutan, semakin banyak penandaan yang dilakukan, maka semakin tinggi level teritori yang dapat diciptakan.

Fitur desain diketahui dapat digunakan untuk mendefinisikan batas-batas atau untuk pengklaiman kepemilikan teritori. Newman [6] mengemukakan bahwa teritori dapat diciptakan dengan fitur-fitur desain yang memiliki makna sebenarnya maupun makna simbolis. Batas-batas dengan makna sebenarnya merujuk pada elemen desain fisik seperti dinding dan pagar. Sedangkan, batasbatas dengan makna simbolis merujuk pada elemen desain seperti perubahan tekstur permukaan jalan dan tanaman-tanaman yang disusun dengan tujuan untuk membatasi suatu teritori.

Setiap kelompok sosial memiliki caranya sendiri-sendiri untuk menghadirkan batasbatas teritori yang diklaimnya. Menurut Altman dan Chemers, perilaku teritorial manusia memiliki fungsi penting dalam meregulasikan interaksi sosial dan menyediakan penandaanpenandaan yang dapat dilihat oleh orang lain untuk menghindari adanya konflik dalam penggunaan sebuah ruang (space). Dengan demikian, kelompok-kelompok sosial dengan teritori yang jelas (well-defined) akan merasa lebih aman untuk berbagi ruang (space) dan bebas dari adanya gangguan orang lain, karena teritorialitas membantu mereka untuk mengontrol interaksi sosial [11].

Pada kelompok sosial rusunawa, analisis teritorialitas dilakukan berdasarkan tingkatan privasi rumah susun yaitu lantai dasar (ruang publik), ruangan di lantai dua (privat), dan koridor unit hunian (semi-privat). Keberadaan teritori kelompok-kelompok sosial pada perbedaan tingkatan privasi di rumah susun akan mempengaruhi jenis dan cara penandaan yang dilakukan kelompok. 
Tabel 1. Klasifikasi Kelompok Sosial di Rusunawa Jatinegara Barat

\begin{tabular}{|c|c|c|c|c|c|c|c|}
\hline Kelompok & Kegiatan & Tujuan & Usia & Lokasi & $\mathrm{P} / \mathrm{SP}$ & Zona Ruang & Waktu \\
\hline Anak-anak & Bermain bola, sepeda, dll & Bermain & $\pm \leq 11$ thn & Koridor hunian & SP & Semi-Privat & Siang-Sore \\
\hline Anak-anak & $\begin{array}{l}\text { Bermain sepeda dan } \\
\text { berbincang }\end{array}$ & Bermain & $\pm \leq 11$ thn & $\begin{array}{l}\text { Jalan depan } \\
\text { rusun }\end{array}$ & SP & Publik & Pagi dan Sore \\
\hline Anak-anak & $\begin{array}{l}\text { Bermain panjat dan melihat } \\
\text { anak remaja bermain bola }\end{array}$ & Bermain & $\pm \leq 11$ thn & Halaman PAUD & SP & Publik & Sore \\
\hline $\begin{array}{l}\text { Anak Remaja } \\
\text { Awal }\end{array}$ & $\begin{array}{l}\text { Duduk, berbincang, dan } \\
\text { melihat anak remaja bermain } \\
\text { bola }\end{array}$ & Bermain & $\pm 12-16$ thn & Tangga taman & SP & Publik & Sore \\
\hline $\begin{array}{l}\text { Anak Remaja } \\
\text { Akhir }\end{array}$ & $\begin{array}{l}\text { Duduk, berbincang, dan } \\
\text { bermain bola }\end{array}$ & Bermain & $\pm 17-25$ thn & Taman & SP & Publik & Sore-Malam \\
\hline $\begin{array}{l}\text { Anak Remaja } \\
\text { akhir }\end{array}$ & $\begin{array}{l}\text { Rapat, berbincang, tidur, } \\
\text { menonton tv, dll }\end{array}$ & $\begin{array}{l}\text { Mempertahanka } \\
\mathrm{n} \text { organisasi }\end{array}$ & $\pm 17-25$ thn & $\begin{array}{l}\text { Ruang Karang } \\
\text { Taruna LT } 2\end{array}$ & $\mathrm{P}$ & Privat & Siang-Malam \\
\hline Ibu-ibu & $\begin{array}{l}\text { Duduk, berbincang, makan, } \\
\text { bertamu, dll }\end{array}$ & $\begin{array}{l}\text { Mengobrol dan } \\
\text { refreshing }\end{array}$ & $\pm 20-50$ thn & Koridor hunian & SP & Semi-Privat & Siang-Malam \\
\hline Ibu-ibu & $\begin{array}{l}\text { Duduk, berbincang, dan } \\
\text { memberi makan anak }\end{array}$ & $\begin{array}{l}\text { Memastikan } \\
\text { keamanan } \\
\text { anaknya }\end{array}$ & $\pm 20-30$ thn & $\begin{array}{l}\text { Jalan depan } \\
\text { rusun }\end{array}$ & SP & Publik & Pagi dan Sore \\
\hline Bapak-Bapak & $\begin{array}{l}\text { Duduk, berbincang, ngopi, } \\
\text { merokok dll }\end{array}$ & $\begin{array}{l}\text { Mengobrol dan } \\
\text { refreshing }\end{array}$ & $\pm \leq 50$ thn & $\begin{array}{l}\text { Warung- } \\
\text { warung makan }\end{array}$ & SP & Publik & Sore-Malam \\
\hline Kakek-kakek & $\begin{array}{l}\text { Duduk, berbincang, ngopi, } \\
\text { merokok dll }\end{array}$ & $\begin{array}{l}\text { Mengobrol, } \\
\text { refreshing, dan } \\
\text { mengawasi } \\
\text { orang luar yang } \\
\text { masuk rusun }\end{array}$ & $\pm \geq 60$ thn & $\begin{array}{l}\text { Dekat tangga } \\
\text { depan rusun }\end{array}$ & SP & Publik & Pagi-Malam \\
\hline \multicolumn{8}{|l|}{ Keterangan: } \\
\hline \multicolumn{8}{|l|}{$\mathrm{P}=$ Permanen } \\
\hline \multicolumn{8}{|c|}{$\mathrm{SP}=$ Semi-Permanen } \\
\hline
\end{tabular}

\section{Lantai Dasar: Penandaan Teritori di Ruang Publik}

Lantai dasar Rusunawa merupakan area yang paling banyak digunakan penghuni untuk berkumpul, karena lantai dasar ini adalah tempat paling umum yang dapat diakses oleh seluruh penghuni. Kelompok sosial yang memilih area lantai dasar sebagai teritorinya antara lain yaitu, anak-anak (jalan), anak-anak (taman), anak remaja awal (tangga), anak remaja akhir (taman), ibu-ibu (jalan), bapakbapak, dan kakek-kakek.

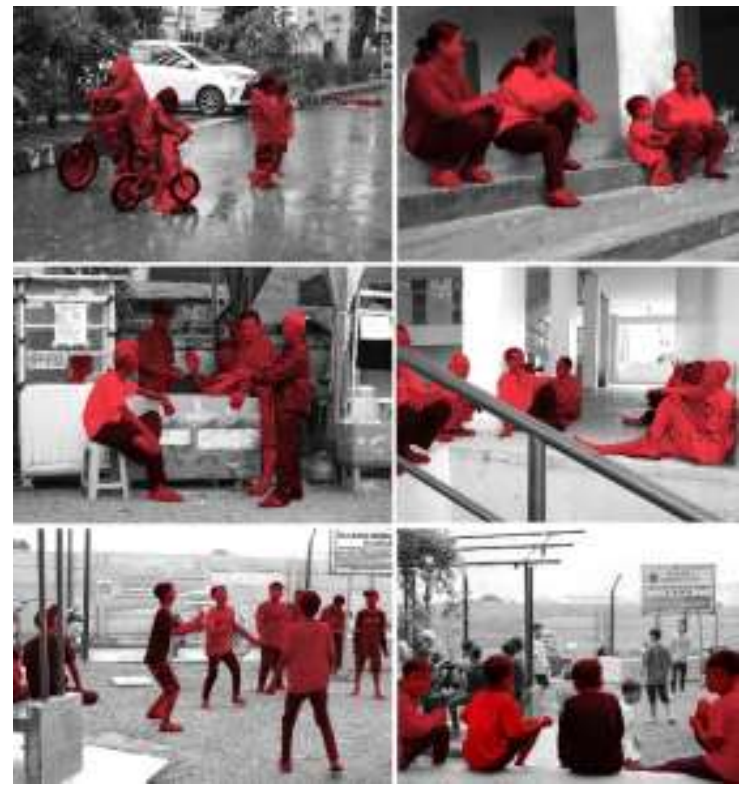

Gambar 2. Tubuh sebagai Pembatas Teritori di Lantai Dasar

(Sumber: Dokumentasi Pribadi, 2017) 
Menurut Brown dan Altman, penandaan dengan penambahan objek teritori pada ruang publik sangatlah minim. Sifatnya yang sementara atau semi-permanen membuat teritori-teritori di lantai dasar mudah berpindah atau direlokasikan sesuai dengan keadaan.[7]

Lantai dasar Rusunawa sebagai ruang publik memungkinkan terciptanya area-area yang dapat dijadikan tempat berkumpul kelompok sosial dengan memanfaatkan elemen-elemen ruang yang ada. Sebagai contoh, bidangbidang horizontal seperti tangga dan pembatas jalan dimaknai oleh kelompok ibu-ibu sebagai batas dan penanda teritorinya dengan kelompok lain.

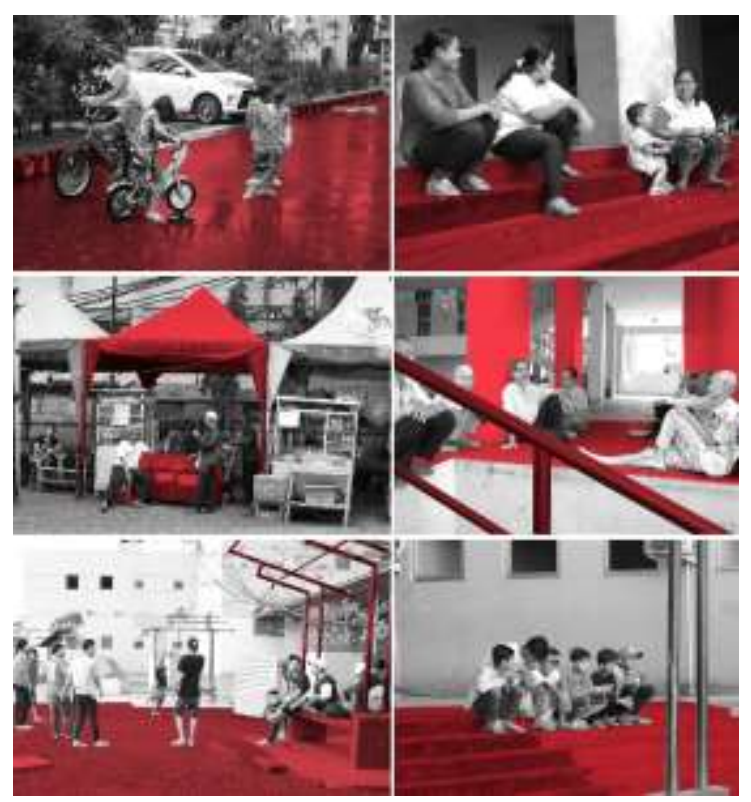

Gambar 3. Elemen Ruang sebagai Objek Teritori di Lantai Dasar

(Sumber: Dokumentasi Pribadi, 2017)

\section{Lantai Dua: Penandaan Teritori di Ruang} Privat

Menurut hierarki teritorial Newman pada bangunan perumahan tingkat tinggi, lantai dua sampai lantai seterusnya terdiri dari area semiprivat dan privat. [12]. Area semi-privat digunakan secara bersama-sama hanya oleh penghuni untuk acara-acara tertentu, sedangkan pada area privat, hanya digunakan oleh warga yang telah memiliki izin kepemilikan atas suatu ruang di lantai tersebut.

Kelompok sosial yang memanfaatkan lantai ini untuk ruang teritorinya adalah kelompok anak remaja Karang Taruna. Peran fitur desain sangat menentukan batas teritori kelompok sosial anak remaja Karang Taruna. Mereka dapat lebih leluasa melakukan penambahan objek teritori sebagai wujud personalisasi kelompoknya.

Pada teritori yang cukup privat bagi anggota kelompok sosial ini, mereka cenderung mengolah ruang tersebut berdasarkan identitas yang mereka miliki atau keinginan untuk diketahui keberadaannya dengan memperlihatkan sesuatu yang berbeda. Pemberian warna dinding luar yang berbeda dan pemasangan banner merupakan penandaan teritori yang mereka lakukan dalam rangka mempersonalisasikan identitas kelompok sosial anak remaja Karang Taruna agar dapat dilihat dari jarak jauh.

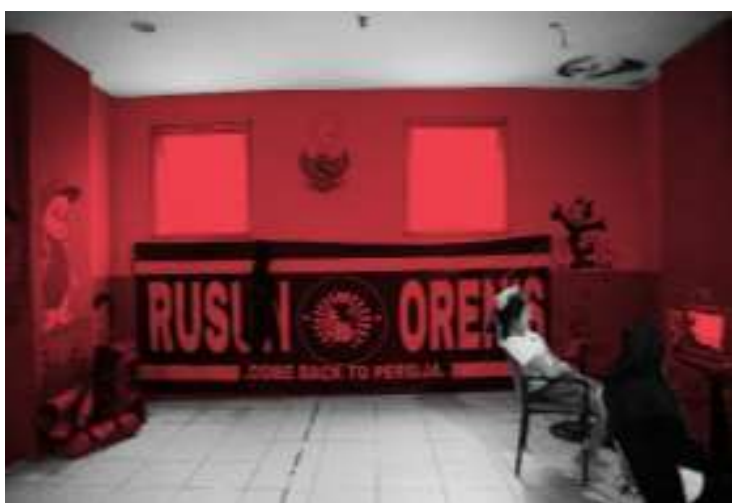

Gambar 4. Fitur Disain sebagai Pembatas Teritori di Lantai Dua

(Sumber: Dokumentasi Pribadi, 2017)

Pembatasan dengan tubuh hanya dilakukan mereka ketika dalam teritorinya ini terdapat beberapa kelompok kecil yang berkumpul untuk berinteraksi.

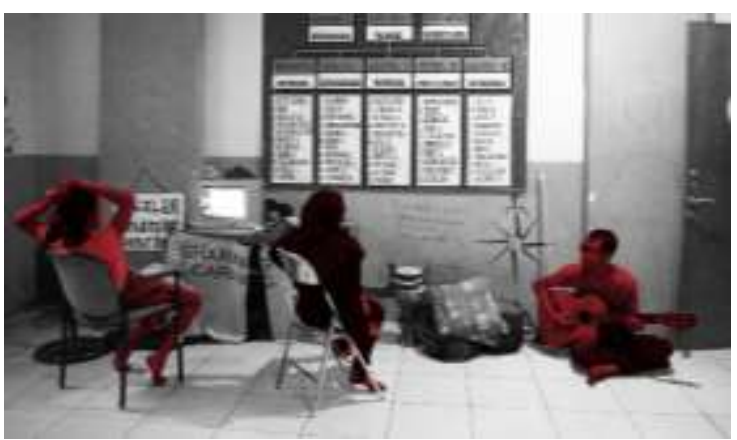

Gambar 5. Tubuh sebagai Pembatas Teritori di Lantai Dua

(Sumber: Dokumentasi Pribadi, 2017)

Koridor Unit Hunian: Penandaan Teritori di Ruang Semi-Privat

Berdasarkan hierarki teritorial pada bangunan perumahan tingkat tinggi oleh Newman, area koridor unit hunian merupakan area semiprivat yang hanya dapat diakses dengan bebas oleh penghuni Rusunawa dan orang 
luar yang sudah mendapatkan izin untuk berkunjung.[12]

Kelompok sosial yang selalu mengisi koridor depan unit hunian di setiap lantainya adalah anak-anak dan ibu-ibu. Penandaan yang dilakukan oleh kedua kelompok sosial ini yaitu dengan tubuh, verbal, dan fisik. Warga penghuni Rusunawa sudah terbiasa meletakkan benda-benda personalnya di depan unit hunian atau koridor.

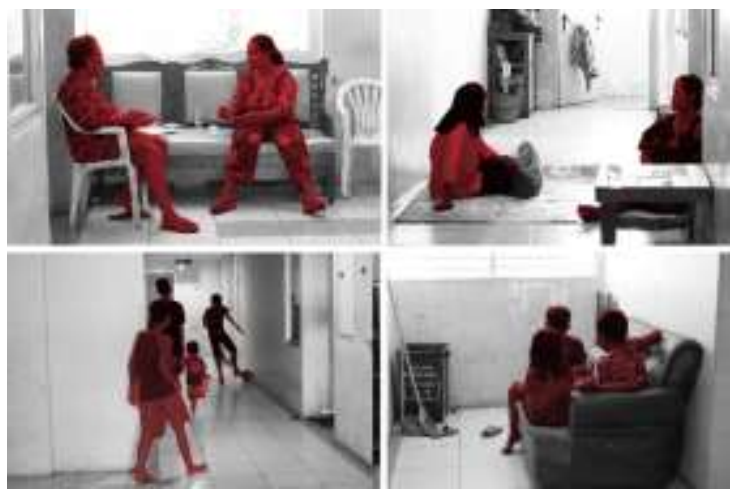

Gambar 6. Tubuh sebagai Pembatas Teritori di Koridor Unit Hunian

(Sumber: Dokumentasi Pribadi, 2017)

Alat-alat bermain yang digunakan oleh kelompok anak-anak, seperti sepeda, kartukartu yang bertebaran, atau sepatu roda menjadi batas teritori. Apabila mereka ingin mengklaim teritori lebih dari yang mereka butuhkan, maka mereka akan meletakkan alatalat bermainnya sebagai barang personal yang menunjukkan bahwa area tersebut sedang mereka klaim untuk sementara. Teritori yang mereka klaim pun tidak jarang berpindahpindah dari ujung koridor satu ke ujung koridor lainnya, selama di sana terdapat keramaian, orang-orang yang mereka kenal, atau dekat dengan unit hunian salah satu anggota kelompok sosial anak-anak ini.
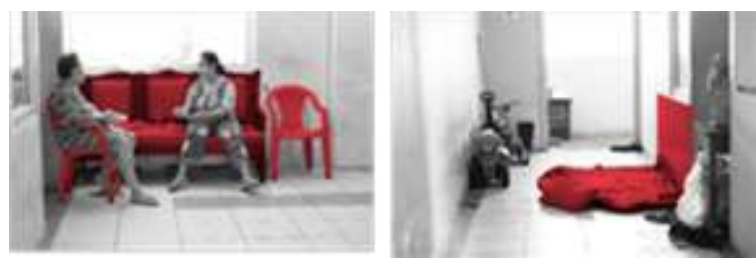

\section{Gambar 7. Fitur Disain sebagai Pembatas Teritori di Koridor Unit Hunian}

(Sumber: Dokumentasi Pribadi, 2017)

Penandaan batas menggunakan objek banyak sekali digunakan oleh kelompok sosial ibu-ibu (koridor). Objek dapat berupa elemen arsitektural bangunan Rusunawa ataupun barang-barang personal milik penghuni. Areaarea pojok atau ujung koridor pada setiap lantainya menjadi teritori dari kelompok sosial ini. Dengan berada di pojok koridor, mereka mampu mendapatkan kemudahan mengamati keadaan hunian di sekitarnya.

Dalam rangka guna mengklaim area di koridor sebagai teritori berkumpulnya, mereka meletakkan sofa, kursi, dan meja di depan unit huniannya. Bagi mereka yang tidak memiliki sofa atau kursi, maka mereka ganti dengan menggelar tikar, karpet, atau kasur lantai. Barang-barang yang mereka letakkan di depan huniannya, menjadi penanda bahwa area tersebut merupakan teritorinya.

\section{Teritorialitas Kelompok Sosial sebagai Proses Home-Making Warga Relokasi}

Bedasarkan hasil pengamatan di Rusunawa Jatinegara Barat, teritorialitas kelompokkelompok sosial penghuni terindikasi sebagai bagian dari proses home-making penghuni yang sebelumnya merupakan warga relokasi kampung padat. Pemilihan lokasi ruang teritori serta kesaaman kegiatan dan tujuan dalam kelompok sosial dipicu oleh keinginan dari individu maupun kelompok untuk mencapai rsa aman, nyaman dan rasa memiliki di hunian yang baru.

Ruang teritori kelompok-kelompok sosial yang ada di lantai dasar bertujuan untuk mendapatkan ruang terbuka yang dapat memberikan mereka ruang aktivitas bersama yang luas, pencahayaan alami, udara segar, dan suasana yang berbeda dari keadaan dalan Rusunawa. Keterbatasan luasan unit hunian dan koridor antar unit membuat mereka merasa sempit dan sesak berada area unit.

Selain itu, pada lantai dasar memungkinkan penghuni untuk mengawasi lingkungan hunian. Kelompok sosial anak-anak mengklaim area jalan memanfaatkan ruang tersebut sebagai ruang teritori untuk arena bermain sepeda, sepatu roda, dan hujan-hujanan. Sedangkan anak-anak yang membuat teritorinya di sepanjang koridor memanfaatkan ruang tersebut sebagai ruang teritori untuk arena bermain sepeda, sepatu roda, bola, atau hanya sekedar berkumpul untuk mengobrol di depan unit hunian. Kemudian, anak-anak yang mengklaim halaman depan PAUD dekat taman memanfaatkan ruang tersebut sebagai ruang teritori untuk memperhatikan anak remaja bermain, memanjat pagar, memetik daun dan mengolahnya di halaman PAUD, serta 
bermain dengan mainan yang ada di halaman tersebut.

Kelompok sosial ibu-ibu berada di lantai dasar berkumpul dan mengklaim ruas jalan sebagai ruang teritorinya. Teritori yang mereka klaim berada di sepanjang jalan bermain anakanaknya, karena area ini terbuka dan mudah terlihat orang banyak. Kepentingan mereka adalah menjaga keamanan anak-anaknya saat bermain.

Kelompok sosial bapak-bapak, memanfaatkan warung di bawah tenda kosong dan meja-meja makan kosong di deretan pedagang Rusunawa. Kelompok ini mengambil teritori yang berada dekat dengan warung-warung makanan dan minum, mereka selalu memesan makanan ringan, merokok, dan minum kopi. Waktu berkumpul mereka adalah waktu pulang kerja, malam, dan hari-hari libur.

Ruang teritori kelompok sosial yang ada di lantai dua bertujuan untuk mendapatkan ruang yang lebih tertutup untuk mewadahi kegiatan kelompoknya. Organisasi Karang Taruna merupakan satu-satunya kelompok sosial yang memiliki hak dan kewajiban secara formal untuk menempati dan mengelola satu ruang di lantai dua di Rusunawa. Ruang ini digunakan mereka sebagai tempat untuk mengadakan kegiatan yang bersifat eksklusif seperti rapat anggota. Namun demikian, pemilihan ruang teritori yang menghadap atau berdekatan dengan aula mengindikasikan keinginan eksistensi teritori mereka agar dapat disadari oleh orang banyak.

Ruang teritori kelompok-kelompok sosial pada koridor-koridor unit hunian bertujuan untuk mendapatkan ruang bersama yang tidak jauh dari unit huniannya, sehingga dapat berinteraksi dengan memaksimalkan pengawasan pada unit huniannya. Selain itu, ruang teritori ini juga merupakan ekstensi unit hunian yang dapat menghadirkan personalisasi serta identitas penghuni.

Kelompok sosial anak-anak memanfaatkan koridor unit hunian Rusunawa untuk kebutuhan mereka akan area yang lebih luas, terbuka, namun tetap dekat dengan unit sebagai ruang bermain kapanpun mereka inginkan. Sebagian besar anak-anak yang menggunakan koridor sebagai tempat bermainnya merupakan kelompok anak-anak yang tinggal di lantai yang sama. Apabila koridor masih mampu mewadahi kegiatan bermain mereka, mereka lebih memilih bermain di koridor dibandingkan harus turun ke lantai dasar terlebih dahulu.

Kelompok sosial ibu-ibu memanfaatkan koridor depan unit huniannya sebagai ruang teritori untuk kebutuhan ruang komunal dan ekstensi dari unitnya. Sebagai ruang komunal, ruang teritori ini dimanfaatkan kelompok untuk berkumpul dalam waktu cukup lama, bukan hanya sekedar tegur sapa. Aktivitas yang mereka lakukan yaitu, mengobrol, makan bersama, dan arisan. Seain itu, kelompok ini juga meletakkan benda-benda personalnya di depan unit hunian atau koridor. Unit hunian yang ditempati tidak cukup luas untuk menampung semua barang-barang miliknya, sehingga area koridor depan unit hunian menjadi perluasan dari dalam yang juga dapat menciptakan personalisasi atas identitas setiap penghuninya.

\section{KESIMPULAN}

Relokasi warga kampung padat ke rumah susun sarat dengan masalah ketidakmampuan ruang hunian yang tersedia untuk mewadahi terciptanya interaksi sosial warga yang merupakan salah satu kultur bermukim di kampung. Dalam praktek penyediaan hunian bagi Masyarakat Berpenghasilan Rendah khususnya bagi warga relokasi kampung padat ke Rusunawa perlu mempertimbangkan kultur bermukim para calon menghuni. Hal ini perlu terimplementasikan melalui perancangan rusunawa yang tidak individualis.

Pada dasarnya, kebutuhan manusia akan sebuah tempat yang dapat mereka klaim dan kontrol atas nama individu atau kelompok menjadi alasan dari terciptanya teritori dan teritorialitas. Hasil penelitian pada ruang-ruang teritori kelompok-kelompok sosial di Rusunawa Jatinegara Barat mengindikasikan adanya proses home-making penghuni untuk menghadirkan suasana dan nilai-nilai 'rumah' di hunian yang baru. Selain itu, kelompokkelompok sosial yang terbentuk membantu setiap individu dalam proses home-making nya.

Rusunawa Jatinegara Barat memiliki banyak area di dalamnya yang diklaim oleh kelompokkelompok sosial sebagai teritori mereka. Kelompok-kelompok sosial tersebut melakukan teritorialitas atau perilaku teritorial guna menjaga dan mempertahankan suatu teritori yang telah mereka maknai dan penting baginya. Aspek kultural dalam membentuk ruang berkumpul yang dimiliki oleh kelompok 
sosial Rusunawa juga mempengaruhi cara mereka menentukan sikap teritorialitasnya.

Pilihan lokasi ruang teritori setiap kelompok sosial pada dasarnya bertujuan untuk memenuhi kebutuhan kenyamanan pada ruang bermukim seperti pilihan lokasi teritori pada ruang terbuka bertujuan untuk mendapatkan sirkulasi udara yang baik dan area yang bebas pandang. Semakin tinggi interaksi sosial yang ingin mereka capai, maka semakin sedikit pula intervensi penambahan objek teritori oleh warga. Dengan begitu, dapat memberi peluang kepada kelompok-kelompok sosial tersebut untuk melakukan pengamatan di sekitarnya, yang selanjutnya dapat meningkatkan rasa aman penghuni dan menjauhkan Rusunawa dari berbagai kemungkinan terjadinya kriminalitas.

Terciptanya ruang-ruang teritori sebagai ruang interaksi kelompok-kelompok sosial, membentuk sikap teritorialitas yang mampu meningkatkan rasa tanggung jawab dalam menjaga dan memelihara lingkungannya. Dengan demikian teritorialitas menjadi bagian dari proses untuk menghadirkan 'rumah' yang aman, nyaman dan dimiliki bagi penghuninya.

Perancangan hunian diharapkan mempertimbangkan kultur bermukim calon penghuninya sehingga hunian tersebut dapat meningkatkan kualitas hidup penghuninya.

\section{DAFTAR PUSTAKA}

[1] Bourne, L. S. (1981). The Geography of Housing. London: Edward Arnold.

[2] Wang, B. (2016). Emotions and homemaking: Performing cosmopolitan sociability among first generation new Chinese migrants in New Zealand. Asian and Pacific Migration Journal. Vol 25 (2), 130-147.

[3] Clark, W.A.V., Dieleman, F.M. (1996). Households and Housing: Choices and Outcomes in the Housing Market. New Brunswick, NJ: CUPR Press.

[4] Budihardjo, E. (2006). Percikan Masalah Arsitektur, Perumahan, Perkotaan. Gadjah Mada University Press: Yogyakarta.

[5] Sack, D, R. (1983). Human Territoriality: A Theory. Annals of the Association of American Geographers, 73, 55-74.

[6] Chung, M, Yun. (2000). User's Perceptions of Territoriality in Residence Hall Rooms. A Thesis of University of Minnesota for the Degree of Doctor of Philosophy.

[7] Brown, B. B. (1987). "Territoriality". Dalam D. Stokols, \& I. Altman (Eds), Handbook of Environmental Psychology. John Wiley \& Sons: New York.

[8] Brown, S. dan Brown, T. (2011). Towards a Model of Human Territory. Proceeding of the Academy of Organizational Culture, Communications and Conflict, 16, 31-37.

[9] Butcher, M. (2010). From "fish out of water" to "fitting in": The challenge of re-placing home in a mobile world. Population, Space and Place. 16:23-26.

[10] Soekanto, S. (2012). Sosiologi Suatu Pengantar. Rajawali Pers: Jakarta.

[11] Kaya, N \& Weber, M, J. (2003). Territorial Behavior in Residence Halls: A CrossCultural Study. Environment and Behavior, 35, 400-414.

[12] Lang, J. (1987). Privacy, Territoriality, and, Personal Space-Proxemic Theory. Dalam J, Lang, Creating Architectural Theory: The Role of the Behavioral Sciences in Environmental Design. Van Nostrand Reinhold: New York. 
